\title{
The Improvement of Students' Problem-Solving Skills Through the 5E Learning Model
}

\author{
Haris Rosdianto ${ }^{1}$, Chat Teeka ${ }^{2}$ \\ ${ }^{1}$ Department of Physics Education, STKIP Singkawang, Indonesia \\ 2Physics Education Program, Faculty of Science and Technology, Suan Dusit University, Thailand \\ e-mail: harisrosdianto@yahoo.com,chat.teeka@gmail.com
}

\begin{abstract}
This research aimed to describe the effect of the 5E learning model on students' problemsolving skills in the topic of static fluid. It is a pre-experimental study with One Group Pretest-Posttest Design. The population in this research was all eighth-grade students of SMP Torsina Singkawang. The sampling technique used in this study was purposive sampling with a total sample of 23 students. Because it is not normally distributed, the data were analyzed using a non-parametric statistical test, which is Mc Nemar Test. It was obtained the value of $X^{2}$ obtained $>X^{2}$ critical or $15.059>3.841$. It means that $H_{0}$ was rejected, and $H_{a}$ was accepted at the level of significance $\alpha=0.05$. So it can be concluded that the $5 E$ learning model has a positive effect on students' problem-solving skills in the topic of static fluid.
\end{abstract}

Keywords: 5E Learning Model, Problem-solving Skills, Static Fluid, Mc Nemar Test

\section{Introduction}

The purpose of physics learning in school is not just to encourage students to get satisfactory learning outcomes with learning completeness criteria that reach 100 percent. One way that can be done in physics learning to improve the quality of learning is to develop students' abilities in solving physical problems through scientific processes using scientific methods (Rosdianto, 2017a; Taufik et al., 2010). The ability to provide new ideas and apply them in solving problems that include curiosity, the desire to ask questions, always want to find new experiences, can also be trained through creativity tests given to the students (Astawan \& Mustika, 2013). It is consistent with physics characteristics that involve creative, imagination, and discovery activities that can encourage students to develop divergent thinking (Hariawan et al., 2013; Trianggono, 2017). According to Eggen and Kauchac, curiosity, and the desire to solve problems are the basis of students' creative attitudes, which show that students can create and work creatively (Sambada, 2012). From the statement above, it can be stated that students' ability to solve problems has implications with their learning outcomes in physics learning. For this reason, students' ability to recall previous topics needs to get more intense attention (Woods et al., 1997; Gertner \& VanLehn, 2000).

The students' ability to recall previous lessons relating to a problem, measured through recall lessons learned quickly, accuracy in creation, sharpness in distinguishing concepts, and accuracy in solving problems is essential to be taught to students (Rosdianto, 2017b; Jauhari \& Suhaudi, 2010). According to Krulik and Rudnick, problem-solving is an individual or group effort to find answers based on prior understanding in order to meet the demands of an unusual situation (Kariawan et al., 2015; Suardani et al., 2014). Heller et al. said that learning could be done by providing strategies on how to solve these problems to improve the problem-solving abilities faced by students in physics (Kariawan et al., 2015). Heller develops a problem-solving strategy that refers to five stages of problem-solving including 1) focus the problem, 2) describe the physics concepts, 3) plan the solution, 4) execute the plan, and 5) evaluate the solution. So, it can be concluded that problem-solving can be interpreted as a process of eliminating existing problems that relate to physics concepts in solving problems (Aji et al., 2017; Azizah et al., 2015). Physics problem solving is a method of solving several problems related to physics (Unaifah \& Suprapto, 2014), while the ability to solve problems in physics is the ability to use a method to solve some problems in physics (Dewi et al., 2014; Hastuti et al., 2016). Thus, students' ability to solve problems needs to be 
trained so that when faced with a problem, they can determine what steps need to be taken to solve the problem (Mayer, 1998; Dufresne, 1997). Innovative strategies and approaches from teachers are needed to facilitate students to improve their ability to solve problems (Kalelioglu \& Gülbahar, 2014; Bolton \& Ross, 1997).

Some of the strategies applied by most teachers today do not seem to be able to facilitate students to be able to improve their problem-solving skills in physics learning (Mauke et al., 2013). Various learning activities are still dominated by teachers so that students are less active in the learning process (Sayyadi et al., 2016; Rosdianto et al., 2017; Venisari et al., 2015). So that the opportunity for students to improve their problem-solving skills is still low. Empowerment of problem-solving abilities is critical to be developed for students (Nurohman et al., 2014; Pratiwi et al., 2015). Problem-solving skills can improve students' verbal skills so that their understanding of physics concepts is getting better (Balci et al., 2006; Iklima et al., 2016). The strategy that can be applied is by implementing a learning process that is more student-centered. Students do not just listen to the explanation from the teacher, but students are encouraged to discuss, expand their perspective, and more actively convey their opinions and arguments (Snyder \& Snyder, 2008; Gok, 2010).

Most of the teachers have implemented multi strategies in the learning process, but the method most often used is the lecturing and question and answer method (Lestari, 2015; Ratnaningdyah, 2017). It has an impact on students' inability to express their opinions when they get problems from the teacher, and students' problem-solving skills will be difficult to be developed (Jannah et al., 2015; Markawi, 2015). Based on this, students' low ability to solve problems occurs in schools in Indonesia as a whole.

The low problem-solving skills also occur in SMP Torsina Singkawang. Based on the results of interviews conducted by researchers with science teachers at school, It is known that in learning activities, teachers do not only focus on student learning outcomes, teachers also try to improve students' conceptual understanding. However, due to time constraints in learning activities, teachers' efforts to improve students' conceptual understanding are limited to the discussion of concepts. When faced with problems that occur, students have difficulty in solving these problems. To support the interview data, the researchers then observed what the learning process was like in the classroom. Based on observations, it appears that students are confused when asked to solve problems related to the physics phenomena that occur around them. There is no further effort from the teacher to guide students in solving these problems due to limited time. From the results of observations, it can be concluded that efforts to improve students' ability to solve problems are still not optimal. To support the observation results, the researcher provides a test to measure the level of students' problem-solving skills. The test results show that only $10 \%$ of all SMP Torsina Singkawang students have sufficient levels of problem-solving skills. Furthermore, researchers conducted interviews with several students with relatively low problem-solving skills. The students stated that the physics concepts discussed in learning activities are only contextually. So that when they have difficulty in answering questions, they relate it to physics concepts that they understand contextually as well.

A learning model is needed to overcome the students' low skills in solving problems. One model that can be used is a $5 \mathrm{E}$ learning model. The $5 \mathrm{E}$ learning model is a studentcentered model that allows students to be more active in learning activities, so they can master the competencies that must be achieved (Acisli et al., 2011; Duran \& Duran, 2004). The stages of the 5E learning model are engagement, exploration, explanation, elaboration, and evaluation (Irhamna et al., 2017).

On the engagement stage, the teacher tries to arouse students' interest and curiosity about the topic of the lesson. This activity is carried out by asking questions about factual processes in daily life (Reif et al., 1976). Thus, students will give a response or answer, then the student's answer is used by the teacher to find out the students' initial knowledge of the topic to be discussed (Bascones et al., 1985).

In the exploration stage, small groups of 2-4 students are formed, then they are allowed to work together in small groups without teacher involvement directly. In this group, students are encouraged to try alternative solutions (Schoenfeld, 1980), doing observations 
(Norman, 1988) and record observations along with ideas or opinions that develop in the discussion (Borkowski et al., 1989). In this phase, the teacher acts as a facilitator (Mumford et al., 1996).

At the explanation stage, the teacher is required to encourage students to explain a concept with their sentences, ask for evidence and clarification on students' explanations, and listen critically to each other's explanations between students. Activities in this phase aim to complete, perfect, and develop concepts that have been obtained by students (Anderson, 1993). Students are required to explain the concepts learned in their own words (Larkin \& Reif, 1979). In this phase, students are expected to find terms from concepts that have been learned (Hollingworth \& McLoughlin, 2001).

In the elaboration stage, the teacher provides clarification on students' ideas, which still have misconceptions and allows students to explain the concepts in their concrete structure by linking or developing concepts and skills that they acquired. This learning activity directs students to apply the concepts they have learned (Boggiano, 1993) to make connections between concepts and apply them to new situations through advanced practical activities that can strengthen and expand the concepts that have been learned (Gabel, 1984).

The final stage of the $5 \mathrm{E}$ learning model is evaluation. At this stage, the teacher can observe students' knowledge or understanding in applying new concepts (Udayani et al., 2014). Students are given questions to diagnose the implementation of learning activities and analyze the level of student understanding of the concepts obtained (Kazdin et al., 1992).

Like other learning models, the $5 \mathrm{E}$ learning model has its advantages and disadvantages. The advantages of the $5 \mathrm{E}$ learning model are: 1) can increase learning motivation because students are actively involved in the learning process, 2) help develop students' scientific attitudes, and 3) learning activities become more meaningful (Wibowo, 2010). The disadvantages of the 5E learning model that must always be anticipated are: 1 ) learning effectiveness is low if the teacher does not understand the topic and learning steps, 2) demanding sincerity and creativity from the teacher in designing and implementing the learning process, and 3 ) requires more planned and organized classroom management (Wilder \& Shuttleworth, 2005).

The researcher has anticipated covering the disadvantages of the $5 \mathrm{E}$ learning model so that this model can be applied effectively in learning. Anticipation efforts carried out by researchers in this study are as follows: 1 ) the researcher prepares himself in mastering the learning material and arranges structured learning steps, 2) researcher tries to be more creative in the learning process so that students do not feel bored and burdened with material that is a little complicated.

Through the implementation of the $5 \mathrm{E}$ learning model, it is expected to have a significant effect on improving students' problem-solving skills. So, this model can be used as an alternative for teachers in physics learning at school.

\section{Methods}

The type of this research is the pre-experimental study with One Group PretestPosttest Design. This type of research was chosen because students' problem-solving abilities in the population were not uniform, so it was not possible to use a quasi-experiment type. The population in this research was all eighth-grade students of SMP Torsina Singkawang. The selection of all eighth-grade students of Torsina Middle School as the population in this study was based on the results of the initial research, which indicated that all students in the population had relatively low problem-solving abilities. So that research can be carried out more effectively and efficiently, the researcher sets a research sample that is expected can represent the entire population. The sampling technique used in this study was purposive sampling with a total sample of 23 students, with the consideration that the level of their problem-solving skills is the lowest.

The variables in this research consist of independent and dependent variables. The independent variable in this study is the $5 \mathrm{E}$ learning model, while the dependent variable is the students' problem-solving skills after the 5E learning model is applied in learning 
activities. The test used is a description test to measure the level of students' problemsolving skills. Data collection instruments used were pretest and posttest sheets. The number of questions given was 15 description questions for the pretest and posttest. Before use, the instrument is tested first to find out if the instrument were valid based on the assessment from three experts and reliable based on the results of the reliability test using the Cronbach Alpha so that it can be used in this research.

From the validity test, the researcher revised the instrument based on suggestions and input from the validators, three revisions for the pretest instrument, and four revisions for the posttest instrument. After the instrument is declared valid, the researcher then performs a reliability test by testing the instrument to students in other schools that have the same criteria as the school where the research will be conducted. From the results of the reliability test, it was found that the instrument reliability values were 0.78 and 0.77 , with a high category for the pretest and posttest. So that the instrument is declared feasible to be used in research.

The data were analyzed using $\mathrm{N}$-Gain to see whether there is an improvement in problem-solving skills, as in equation 1.

$$
<g>=\frac{S_{\text {posttest }}-S_{\text {pretest }}}{S_{\text {max }}-S_{\text {pretest }}}
$$

Where $\langle\mathrm{g}\rangle$ is the normalized gain, $S_{\text {posttest }}$ is the posttest average score, $S_{\text {pretest }}$ is the average score of the pretest, and $S_{\max }$ is the possible maximum score. The N-Gain criteria obtained are shown in table 1.

Table 1. Criteria of N-Gain

\begin{tabular}{cc}
\hline Gain Score & Criteria \\
\hline$<\mathrm{g}>\geq 0.7$ & High \\
$0.3 \leq<\mathrm{g}><0.7$ & Fair \\
$<\mathrm{g}><0.3$ & Poor \\
\hline
\end{tabular}

To find out whether the research hypothesis is supported by the data obtained, the hypothesis must be tested. However, before the normality test needs to be done to determine whether the obtained data is normally distributed or not. The normality test is carried out by using the Chi-square test (Sugiyono, 2007) as in equation 2 ,

$$
\chi^{2}=\sum_{i=1}^{k} \frac{\left(f_{o}-f_{e}\right)^{2}}{f_{e}}
$$

Where $f_{o}$ is the observation frequency, and $f_{e}$ is the expected frequency. The test criterion used at $\mathrm{df}=(\mathrm{k}-3)$ with significance level $\alpha=0.05$ is if $x^{2}$ obtained $<x^{2}$ critical, then the data is normally distributed. If it is normally distributed, then the data obtained is analyzed using paired t-test (Sugiyono, 2007) with a pair of the hypothesis as follows:

$\mathrm{H}_{0}$ : There is no effect of the $5 \mathrm{E}$ learning model on students' problem-solving skills in the topic of static fluid

$\mathrm{H}_{\mathrm{a}}$ : There is an effect of the $5 \mathrm{E}$ learning model on students' problem-solving skills in the topic of static fluid. 
The equation used was:

$$
t_{\text {obtained }}=\frac{X-Y}{\sqrt{\frac{s_{x}^{2}}{n_{x}}+\frac{s_{y}^{2}}{n_{y}}-2 r\left(\frac{s_{x}}{\sqrt{n_{x}}}\right)\left(\frac{s_{y}}{\sqrt{n_{y}}}\right)}}
$$

With the test criterion: $H_{0}$ was accepted if $t_{\text {obtained }} \leq t_{\text {critical }}$ at significance level $\alpha=0.05$ and $d f$ $=(n-1)$, as well as for other $t$ values $H_{0}$ was rejected.

If the data is not normally distributed, then non-parametric statistical tests are used, which is Mc Nemar test (Sugiyono, 2007), with pairs of the hypothesis as follows:

$\mathrm{H}_{0}$ : There is no effect of the $5 \mathrm{E}$ learning model on students' problem-solving skills in the topic of static fluid

$\mathrm{H}_{\mathrm{a}}$ : There is an effect of the $5 \mathrm{E}$ learning model on students' problem-solving skills in the topic of static fluid.

The equation used was:

$$
\chi^{2}=\frac{(|A-D|-1)^{2}}{A+D}
$$

With the test criterion $\mathrm{H}_{0}$ was accepted if $X^{2}$ obtained $\leq X^{2}$ critical at significance level $\alpha=0.05$ and $\mathrm{df}=(\mathrm{n}-1)$, as well as for other $\mathrm{X}^{2}$ values $\mathrm{H}_{0}$ was rejected.

\section{Findings and Discussions}

Data recapitulation from the results of the pretest and posttest can be seen in table 2 .

Table 2. Pretest and Posttest Results

\begin{tabular}{cccc}
\hline & Pretest & Posttest & Difference \\
\hline Average Score & 52,17 & 72,83 & 20,65 \\
Standard Deviation & 12,32 & 7,20 & \\
Highest Score & 75 & 75 & \\
Lowest Score & 25 & 50 & \\
\hline
\end{tabular}

From table 2, although the maximum value between pretest and posttest is the same, the average posttest score is much higher than the average pretest score. It shows that the students' problem-solving skills increased after the treatment with the $5 \mathrm{E}$ learning model. It means that the $5 \mathrm{E}$ learning model is useful for improving problem-solving skills. It was proved by obtained $\mathrm{N}$-Gain value by 0.43 with a medium category.

Furthermore, statistical tests were conducted to strengthen the results of the N-Gain analysis. The first step in data analysis is to conduct a data normality test that aims to measure whether the data is normally distributed or not. If it is normally distributed, parametric statistical tests are used. However, if it is not normally distributed, non-parametric statistical tests are used. The summary of pretest and posttest data normality tests can be seen in tables 3 and 4.

Table 3. Summary of Pretest Data Normality Test

\begin{tabular}{ccc}
\hline $\mathbf{X}^{2}$ obtained from Pretest Score & $\mathbf{X}^{2}$ critical from Pretest Score & Normality Test \\
\hline 67.05 & 7.815 & Not Normal \\
\hline
\end{tabular}


Table 4. Summary of posttest data normality test

\begin{tabular}{ccc}
\hline $\begin{array}{c}\mathbf{X}^{2} \text { obtained from } \\
\text { Posttest Score }\end{array}$ & $\begin{array}{c}\mathbf{X}^{2} \text { critical from } \\
\text { Posttest Score }\end{array}$ & Normality Test \\
\hline 135.45 & 7.815 & Not Normal \\
\hline
\end{tabular}

From tables 3 and 4, it was found that the pretest and posttest scores of students were both not normally distributed. After ensuring that the data is not normally distributed, the statistical test used is the non-parametric statistical test, which is the Mc Nemar test. The value of $X^{2}$ obtained $>X^{2}$ critical or $15.059>3.841$, then $\mathrm{H}_{0}$ was rejected, and $\mathrm{H}_{\mathrm{a}}$ accepted at the level of significance $\alpha=0.05$.

The results showed that there was an effect of the $5 \mathrm{E}$ learning model on students' problem-solving skills in the topic of Static Fluid at SMP Torsina Singkawang, prooved by the average posttest score that is higher than the average pretest score. It is also proved by statistical tests to test the research hypothesis, obtained the value of $X^{2}$ obtained $>X^{2}$ critical, then $\mathrm{H}_{0}$ was rejected, and $\mathrm{H}_{\mathrm{a}}$ accepted at the level of significance $\alpha=0.05$. The results of this research are supported by Apriyanti et al. (2013), Asna (2016), Budprom et al. (2010), Gazali et al. (2015), and Irhamna et al. (2017) which stated that the 5E learning model has a significant effect on students' problem-solving skills aspect in critical thinking skills. It is also supported by researches conducted by Latifa et al. (2017), Mayangsari et al. (2016), Murdhiyah (2014), Nadiya et al. (2016), Novianti et al. (2014), and Udayani et al. (2014) which stated that the implementation of 5E learning model is effective in improving students' problem-solving skills aspect in critical thinking skills.

\section{Conclusions}

Students' problem-solving skills were increased after the $5 \mathrm{E}$ learning model was implemented. It can be seen from the average score of students' learning outcomes after being treated, which is higher than the average score of students' learning outcomes before being treated.

There was an effect of the $5 \mathrm{E}$ learning model on students' problem-solving skills in class VIII of SMP Torsina Singkawang in the topic of Static Fluids. This can be seen from the hypothesis test with the value of $x^{2}$ obtained $>X^{2}$ critical with a significance level of $5 \%$.

\section{References}

Acisli, S., Yalcin, S. A., \& Turgur, U. (2011). Effects of the 5E learning model on students' academic achievements in movement and force issues. Procedia Social and Behavioral Sciences 15 (2011), 2459-2462.

Aji, S. D., Hudha, M. N., \& Rismawati, A. Y. (2017). Pengembangan Modul Pembelajaran Fisika Berbasis Problem Based Learning untuk Meningkatkan Kemampuan Pemecahan Masalah Fisika. Science Education Journal, 1(1), 36-51.

Anderson, J. R. (1993). Problem solving and learning. American Psychologist, 48(1), 35.

Apriyanti, L. G. E., Dantes, N., \& Partadjaya, T. R. (2013). Pengaruh Model Siklus Belajar 5E Terhadap Kemampuan Berpikir Kritis IPA Siswa Kelas V di Desa Penarukan. Mimbar PGSD Undiksha, 1(1).

Asna, R. H. (2016). Implementasi Strategi Pembelajaran Berbasis Inkuiri dengan Siklus Belajar 5E Untuk Meningkatkan Keterampilan Berpikir Kritis. Jurnal Penelitian Pendidikan, 14(2), 154-162.

Astawan, I. G., \& Mustika, I. W. (2013). Meningkatkan Aktivitas Dan Kemampuan Memecahkan Masalah Melalui Pembelajaran Kuantum Teknik Fisika Gasing. Jurnal Pendidikan dan Pengajaran, 46(2), 136-144.

Azizah, R., Yuliati, L., \& Latifah, E. (2015). Kesulitan Pemecahan Masalah Fisika Pada Siswa SMA. Jurnal Penelitian Fisika dan Aplikasinya (JPFA), 5(2), 44-50.

Balci, S., Cakiroglu, J., \& Tekkaya, C. (2006). Engagement, Exploration, Explanation, Extension, and Evaluation (5E) Learning Cycle and Conceptual Change Text as Learning Tools. Biochemistry and Molecular Biology Education, 34(3), 199-203. 
Bascones, J., Venezuela, \& Novak, J. D. (1985). Alternative instructional systems and the development of problem-solving skills in physics. The European Journal of Science Education, 7(3), 253-261.

Boggiano, A. K., Flink, C., Shields, A., Seelbach, A., \& Barrett, M. (1993). Use of techniques promoting students' self-determination: Effects on students' analytic problem-solving skills. Motivation and emotion, 17(4), 319-336.

Bolton, J., \& Ross, S. (1997). Developing students' physics problem-solving skills. Physics Education, 32(3), 176.

Borkowski, J. G., Estrada, M. T., Milstead, M., \& Hale, C. A. (1989). General problem-solving skills: Relations between metacognition and strategic processing. Learning Disability Quarterly, 12(1), 57-70.

Budprom, W., Suksringam, P., \& Singsriwo, A. (2010). Effects of Learning Enviromental Education Using the 5E-Learning Cycle with Multiple Intelligences and Teacher's Handbook Approaches on Learning Achievement, Basic Science Process Skills and Critical Thinking of Grade 9 Students. Pakistan Journal of Social Sciences, 7(3), 200204.

Dewi, P. S. U., Sadia, I. W., \& Suma, K. (2014). Pengaruh Model Problem Based Learning Terhadap Kemampuan Pemecahan Masalah Fisika Melalui Pengendalian Bakat Numerik Siswa SMP. Jurnal Pendidikan dan Pembelajaran IPA Indonesia, 4(1).

Dufresne, R. J., Gerace, W. J., \& Leonard, W. J. (1997). Solving physics problems with multiple representations. The Physics Teacher, 35(5), 270-275.

Duran, L. B., \& Duran, E. (2004). The 5E Instructional Model: A Learning Cycle Approach for Inquiry-Based Science Teaching. The Science Education Review, 3(2), 49-58.

Gabel, D. L., Sherwood, R. D., \& Enochs, L. (1984). Problem-solving skills of high school chemistry students. Journal of Research in Science Teaching, 21(2), 221-233.

Gazali, A., Hidayat, A., \& Yuliati, L. (2015). Efektivitas Model Siklus Belajar 5E Terhadap Keterampilan Proses Sains dan Kemampuan Berpikir Kritis Siswa. Jurnal Pendidikan Sains, 3(1), 10-16.

Gertner, A. S., \& VanLehn, K. (2000, June). Andes: A coached problem solving environment for physics. In International conference on intelligent tutoring systems (pp. 133-142). Springer, Berlin, Heidelberg.

Gok, T. (2010). The general assessment of problem solving processes in physics education. Eurasian Journal of Physics and Chemistry Education, 2(2), 110-122.

Hariawan, Kamaluddin, \& Wahyono, U. (2013). Pengaruh Model Pembelajaran Creative Problem Solving Terhadap Kemampuan Memecahkan Masalah Fisika Pada Siswa Kelas XI SMA Negeri 4 Palu. Jurnal Pendidikan Fisika Tadulako (JPFT), 1(2), 48-54.

Hastuti, A., Sahidu, H., \& Gunawan. (2016). Pengaruh Model PBL Berbantuan Media Virtual Tehadap Kemampuan Pemecahan Masalah Fisika. Jurnal Pendidikan Fisika dan Teknologi, 2(3), 129-135.

Hollingworth, R. W., \& McLoughlin, C. (2001). Developing science students' metacognitive problem solving skills online. Australasian Journal of Educational Technology, 17(1).

Iklima, I., Marzal, J., \& Damris, M. (2016). Pengaruh Model Pembelajaran Kooperatif Tipe Team Assisted Individualization dan Self-Efficacy terhadap Kemampuan Pemecahan Masalah Fisika Siswa di MTs N Kota Jambi. Edu-Sains, 5(1), 46-55.

Irhamna, I., Rosdianto, H., \& Murdani, E. (2017). Penerapan Model Learning Cycle 5E untuk Meningkatkan Keterampilan Berpikir Kritis Siswa Pada Materi Fluida Statis Kelas VIII. Jurnal Fisika FLUX, 14(1), 61-64.

Jannah, S. N., Doyan, A., \& Harjono, A. (2015). Pengaruh Model Pembelajaran Kooperatif Dengan Pendekatan Problem Posing Ditinjau Dari Pengetahuan Awal Terhadap Kemampuan Pemecahan Masalah Fisika Siswa SMK. Jurnal Pendidikan Fisika dan Teknologi, 1(4), 256-263.

Jauhari, A., \& Suhaudi, A. (2010). Pengaruh Pembelajaran Pemecahan Masalah Secara Kelompok Kooperatif Terhadap Kemampuan Pemecahan Masalah. Jurnal Pendidikan Matematika dan Sains, 15(1), 13-17. 
Kalelioglu, F., \& Gülbahar, Y. (2014). The Effects of Teaching Programming via Scratch on Problem Solving Skills: A Discussion from Learners' Perspective. Informatics in Education, 13(1), 33-50.

Kariawan, I. G., Sadia, I. W., \& Pujani, N. M. (2015). Pengembangan Perangkat Pembelajaran Fisika Dengan Setting Model Pembelajaran Inkuiri Untuk Meningkatkan Kemampuan Pemecahan Masalah Dan Kemampuan Berpikir Kritis Siswa SMA. Jurnal Pendidikan dan Pembelajaran IPA Indonesia, 5(1).

Kazdin, A. E., Siegel, T. C., \& Bass, D. (1992). Cognitive problem-solving skills training and parent management training in the treatment of antisocial behavior in children. Journal of consulting and clinical psychology, 60(5), 733.

Larkin, J. H., \& Reif, F. (1979). Understanding and teaching problem-solving in physics. European journal of science education, 1(2), 191-203.

Latifa, B. R. A., Verawati, N. N. S. P., \& Harjono, A. (2017). Pengaruh Model Learning Cycle 5E (Engage, Explore, Explain, Elaboration, \& Evaluate) Terhadap Kemampuan Berpikir Kritis Peserta Didik Kelas X MAN 1 Mataram. Jurnal Pendidikan Fisika dan Teknologi, 3(1), 61-67.

Lestari, S. (2015). Meningkatkan Kemampuan Pemecahan Masalah Fisika Kelas XI IIS 1 SMA Muhammadiyah 2 Yogyakarta Melalui Pembelajaran SEA (Starter Experiment Approach). Jurnal IImiah Guru Caraka Olah Pikir Edukatif, 19(2), 66-76.

Markawi, N. (2015). Pengaruh Keterampilan Proses Sains, Penalaran, Dan Pemecahan Masalah Terhadap Hasil Belajar Fisika. Formatif: Jurnal IImiah Pendidikan MIPA, 3(1), 11-25.

Mauke, M., Sadia, I. W., \& Suastra, I. W. (2013). Pengaruh Model Contextual Teaching and Learning Terhadap Pemahaman Konsep dan Kemampuan Pemecahan Masalah dalam Pembelajaran IPA-Fisika di MTs Negeri Negara. Jurnal Pendidikan dan Pembelajaran IPA Indonesia, 3(1).

Mayangsari, E. P., Tukiran, \& Admoko, S. (2016). Pengembangan Lembar Kegiatan Siswa Berorientasi Learning Cycle 5E Untuk Melatihkan Keterampilan Berpikir Kritis Pada Materi Suhu Dan Perubahannya. Pendidikan Sains, 4(3), 1-5.

Mayer, R. E. (1998). Cognitive, metacognitive, and motivational aspects of problem solving. Instructional science, 26(1-2), 49-63.

Mumford, M. D., Baughman, W. A., Threlfall, K. V., Supinski, E. P., \& Costanza, D. P. (1996). Process-based measures of creative problem-solving skills: I. Problem construction. Creativity Research Journal, 9(1), 63-76.

Murdhiyah, N. (2014). Penggunaan Siklus Belajar 5E Untuk Meningkatkan Keterampilan Berpikir Kritis Siswa Mata Pelajaran IPA di Sekolah Dasar. JPGSD, 2(2), 1-10.

Nadiya, Rosdianto, H., \& Murdani, E. (2016). Penerapan Model Pembelajaran Group Investigation (GI) untuk Meningkatkan Keterampilan Berpikir Kritis Siswa pada Materi Gerak Lurus Kelas X. JIPF (Jurnal IImu Pendidikan Fisika), 1(2), 49-51.

Norman, G. R. H. (1988). Problem-solving skills, solving problems and problem-based learning. Medical education, 22(4), 279-286.

Novianti, A., Noor, M. F., \& Susanti, B. H. (2014). Pengaruh Model Pembelajaran Learning Cycle Terhadap Keterampilan Berpikir Kritis Siswa. Edusains, 6(1), 109-116.

Nurohman, A., Ashari, \& Nurhidayati. (2014). Peningkatan Kemampuan Berpikir Kritis dalam Pemecahan Masalah Fisika Menggunakan Model Think Talk Write Berbasis Strategi Pembelajaran Peningkatan Kemampuan Berpikir. Radiasi, 5(1), 15-19.

Pratiwi, N. D., \& Setyarsih, W. (2015). Pengembangan Instrumen Evaluasi Berbasis Taksonomi Structure of the Observed Learning Outcome (SOLO) Untuk Menentukan Profil Kemampuan Siswa dalam Memecahkan Masalah Fluida Statis. Jurnal Inovasi Pendidikan Fisika (JIPF), 4(3), 45-49.

Ratnaningdyah, D. (2017). Penerapan Model Pembelajaran Novick Dipadukan Dengan Strategi Cooperative Problem Solving (CPS) Untuk Meningkatkan Kemampuan Pemecahan Masalah Siswa SMA. Jurnal Wahana Pendidikan Fisika, 2(2), 63-67.

Reif, F., Larkin, J. H., \& Brackett, G. C. (1976). Teaching general learning and problemsolving skills. American Journal of Physics, 44(3), 212-217. 
Rosdianto, H. (2017a). Pengaruh Model Generative Learning Terhadap Hasil Belajar Ranah Kognitif Siswa Pada Materi Hukum Newton. Jurnal Pendidikan Fisika Dan Keilmuan (JPFK), 3(2), 66-69.

Rosdianto, H. (2017b). Students` Conceptual Understanding through Generative Learning Model in Topic "Light". JPI (Jurnal Pendidikan Indonesia), 6(2), 259-262.

Rosdianto, H., Murdani, E., \& Hendra. (2017). The Implementation of POE (Predict Observe Explain) Model to Improve Student's Concept Understanding on Newton's Law. Jurnal Pendidikan Fisika, 6(1), 55-57.

Sambada, D. (2012). Peranan Kreativitas Siswa Terhadap Kemampuan Memecahkan Masalah Fisika Dalam Pembelajaran Kontekstual. Jurnal Penelitian Fisika dan Aplikasinya (JPFA), 2(2), 37-47.

Sayyadi, M., Hidayat, A., \& Muhardjito. (2016). Pengaruh Strategi Pembelajaran Inkuiri Terbimbing Dan Terhadap Kemampuan Pemecahan Masalah Fisika Pada Materi Suhu Dan Kalor Dilihat Dari Kemampuan Awal Siswa. Jurnal Inspirasi Pendidikan, 6(2), 866875.

Schoenfeld, A. H. (1980). Teaching problem-solving skills. The American Mathematical Monthly, 87(10), 794-805.

Snyder, L. G., \& Snyder, M. J. (2008). Teaching critical thinking and problem solving skills. The Journal of Research in Business Education, 50(2), 90.

Suardani, N. N., Swasta, I. B. J., \& Widiyanti, N. L. P. M. (2014). Pengaruh Model Pembelajaran Berbasis Masalah Terhadap Kemampuan Pemecahan Masalah Dan Keterampilan Proses Sains Siswa. Jurnal Pendidikan dan Pembelajaran IPA Indonesia, 4(1).

Sugiyono. (2007). Statistika Untuk Penelitian. Bandung: Alfabeta.

Taufik, M., Sukmadinata, N. S., Abdulhak, I., \& Tumbelaka, B. Y. (2010). Desain Model Pembelajaran Untuk Meningkatkan Kemampuan Pemecahan Masalah Dalam Pembelajaran IPA (Fisika) Sekolah Menengah Pertama di Kota Bandung. Berkala Fisika, 13(2), E31-E44.

Trianggono, M. M. (2017). Analisis Kausalitas Pemahaman Konsep Dengan Kemampuan Berpikir Kreatif Siswa Pada Pemecahan Masalah Fisika. Jurnal Pendidikan Fisika dan Keilmuan (JPFK), 3(1), 1-12.

Udayani, P. A., Kusmariyatni, N., \& Wibawa, I. M. C. (2014). Pengaruh Model Siklus Belajar 5E Terhadap Kemampuan Berpikir Kritis IPA Siswa Kelas IV SD di Desa Kalibukbuk. Mimbar PGSD, 2(1).

Unaifah, F., \& Suprapto, N. (2014). Profil Kemampuan Pemecahan Masalah dan Hasil Belajar Siswa pada Materi Elastisitas Ditinjau dari Gaya Belajar (Learning Style). Jurnal Inovasi Pendidikan Fisika (JIPF), 3(2), 27-32.

Venisari, R., Gunawan, \& Sutrio. (2015). Penerapan Metode Mind Mapping Pada Model Direct Instruction Untuk Meningkatkan Kemampuan Pemecahan Masalah Fisika Siswa SMPN 16 Mataram. Jurnal Pendidikan Fisika dan Teknologi, 1(3), 193-198.

Wibowo, A. (2010). Penerapan Model Pembelajaran Siklus Belajar (Learning Cycle) $5 e$ dalam Meningkatkan Hasil Belajar Siswa Pada Matapelajaran Teknologi Informasi dan Komunikasi (Penelitian Kuasi Eksperimen terhadap Siswa Kelas VII SMPN 1 Lembang Tahun Ajaran 2009/2010). Bandung: UPI.

Wilder, M., \& Shuttleworth, P. (2005). Cell inquiry: A 5E learning cycle lesson. Science Activities, 41(4), 37-43.

Woods, D. R., Hrymak, A. N., Marshall, R. R., Wood, P. E., Crowe, C. M., Hoffman, T. W., ... \& Bouchard, C. K. (1997). Developing problem solving skills: The McMaster problem solving program. Journal of Engineering Education, 86(2), 75-91. 